\title{
Modernization of Downtown Cairo
}

\author{
Rania Shafik, Hussam Salama \\ National Research Center of Egypt, \\ Department of Civil Engineering and Architecture, \\ El Buhouthst, Dokki, 12622 Giza, Egypt
}

\begin{abstract}
Cairo's movement towards modernization was the main influence on the urban development of the city of Cairo till this time. The period from 1805 till 1922 starting from Mohamed Ali's reign till the period of Prince Fouad, the youngest of the deposed Khedive Ismail's sons was the main trigger point for the start of modernization in Egypt and Cairo in particular. This period has featured one of the most dramatic shifts in the history of the city. It was a turning point from the traditional medieval era to modernization and industrialization. The main goal of this paper is to analyze the first developments towards the modernization of downtown Cairo which led later on to a significant change in the urban pattern of the center of Cairo and its expansion. It highlights the importance of studying the development of the city centers which affects the development of the city later on and its urban pattern.
\end{abstract}

Keywords: Urban Development, Downtown development, downtown modernization, urban pattern

\section{INTRODUCTION}

In the traditional period in particular the first half of the nineteenth century, it is very important to mention that Cairo's movement towards modernization was the main influence on the urban development of Cairo at this time. Egypt's first entry into the modernization world was in 1798 , the date of the French Expedition. A change was to come in the shape of the French occupation of Egypt at the hands of Napoleon Bonaparte in 1798 (Al-Sayyid,1985). The presence of the French in Cairo, although not much physical changes were made, showed the Egyptians other views and other philosophies. In the three years of the French occupation on Egypt, the Egyptians came in contact with the full influence of the Western Civilization which made a way for Mohamed Ali later on to introduce a new vision and new reforms. Two major physical changes introduced by the French, worth mentioning as they remained in the city till the present time. First, they re-organized Cairo's administrative sectors into eight large districts. These basic divisions have with some boundary changes, remained in the present administrative organization of the city. (Goldschmidt, 1990) Second, they planned and organized some streets in Cairo which became major axes in Cairo. These streets have ever since become major thoroughfares of the city, indispensable to its present circulation (Abu Lughod, 1971).

\section{INITIATION OF MODERN CAIRO:}

The actual beginning of modernization of downtown Cairo was at the era of Mohamed Ali. Mohamed Ali ruled Egypt from the period of 1805 till 1848.In these fourty three years; he was able to organize a new government, society and new economy. As mentioned by Goldschmidt in the book
Modern Egypt, the seed of contemporary Cairo was contained in THE Cairo that took shape during the first half of the nineteenth century. (Goldschmidt, 1990) He initiated the first step that led Egypt to the modern world to be recognized internationally. Mohamed Ali reign in Egypt is divided into two periods. First period was to settle his rule and eliminate the oppositions. The second period was to make social, administrative, economic and military reforms in Egypt. The research will discuss briefly the first period as it did not influence much the urban foot print of Cairo. In this first period, Mohamed Ali focused on driving the Mamluks out of the country. He did this either by bribing them to join his ranks or fighting the ones who resisted him. His aim was to become the only master and governor of the land. The last Mamluk was destroyed by the famous incident of the "Citadel Slaughter," where all the remaining Mamluks were invited to a ceremony in the citadel in 1811 . They were all killed during the ceremony.

The second period of his reign started after Mohamed Ali got rid of all the Mamluks and started focusing on Egypt's future. (Al-Sayyid,1985) Mohamed Ali had a clear vision for Egypt's development. With the help of his supporters, he had a plan for the improvement in several fields. He believed in expanding the agriculture for export, introducing industrialization of the agricultural raw materials to become self-sufficient, strengthening the army and building up a navy and a merchant marine as well as manufacturing the military weapons and finally improving the education system. (Al-Sayyid,1985)

For agriculture, first he monopolized all the cultivable land of Egypt to bring it back to productivity. Then, he introduced the long staple cotton in 1821 which is one of Egypt's famous products till the present time.

In terms of industrialization, he built textile factories and imported silk worms and mulberry trees from Syria and Lebanon for the production and manufacture of silk in Egypt. Cashmere goats were imported from India to improve the production of wool in Egypt.

As for the army, it went to a process of transformation when it could not obtain men from the Ottoman Empire. Mohamed Ali hired French officers who trained the Egyptian farmers to join the army and become soldiers. After some time, the Egyptian army reached 100,000 soldiers; the senior officers were Ottoman and all the younger officers were all Egyptians. The whole army was armed with the most up to date weapons.

Mohamed Ali began expanding and developing the education system in terms of staff college, engineers, medical surgeons and veterinary surgeons. Schools were opened in Egypt and educational missions sent abroad to learn technology in many fields as well as the field of 
military science. Mohamed Ali saw the necessity for importing technology, and that the education was the only way for the development of Egypt. He believed that education was the key to success and would open the future to Egypt. (Al-Sayyid,1985)

The funding of these programs was through exporting grains to the British armies which were in continuous rising prices and were used to expand the irrigation system. It increases the corps into three a corps a year in some places which bring even more money to fund the projects. Mohamed Ali believed that the country needed to export more than it imported, this was one of the basic principles of such thought. His thoughts were soon translated according to $\mathrm{Al}$ Sayyid Marsot into mercantilist economic planning where an aggressive export policy was made. Therefore, most of the local materials were fabricated for export. To create markets for the new industries, he conquered and created colonies to become the markets which would also provide further raw materials, expertise and manpower for the industry and the army. These colonies led Egypt to take control over the commerce of the region and the significant trade routes. (Al-Sayyid,1985)

\section{IMPACT ON URBAN FABRIC}

The efforts of Mohamed Ali in the city of Cairo did not leave much in its footprint as his successors. However, his work was important as it was more towards the preparation of the land for the future urban expansion of the city. As Janet AbuLughod mentioned:

"The work of Mohamed Ali was to clear the medieval city of her dusty coating; the modern city came into existence in the age that followed, but it would not have taken the shape it did without the preparatory efforts of Egypt's first modern leader." (Abu Lughod, 1971)

Mohamed Ali worked on cleaning the city, leveling the rubbish mounds on the western edge of the city, and filling the ponds and swamps like Azbakiya. New streets were introduced which led to demolishing some buildings later on to improve Cairo's transportation system. Small changes were made in the architecture of the buildings in Cairo like using window panels instead of the Mashrabeya (wooden screen used for windows), introducing western plans instead of inward looking courts. According to Raymond, 2001; one must look deeper in order to perceive this as a sign of rejection of traditional values. (Raymond, 2001)

The footprint of Cairo almost remained the same in 1848 as it had been in 1798 and the real changes were in the era of Mohamed Ali's successors. If an awakening had occurred, then its effects were still barely felt in Cairo. (Abu Lughod, 1971)

\section{FIRST MASTER PLAN OF CAIRO:}

The modern Cairo arose in the next decades in the second half of the nineteenth century with many technological changes which would not have taken place except with the efforts of Mohamed Ali or as Abu-Lughod mentioned Egypt's first modern leader. (Abu Lughod, 1971)

Downtown Cairo is an extension for the old city of Cairo that was shaped for Khedive Ismail vision of transforming it into Paris of the east. This extension was a National Urban Project before 1869 where the city was rapidly constructed for the event of the inauguration of Suez Canal and accomplishing Khedive Ismail's vision of turning it into Paris of the east.

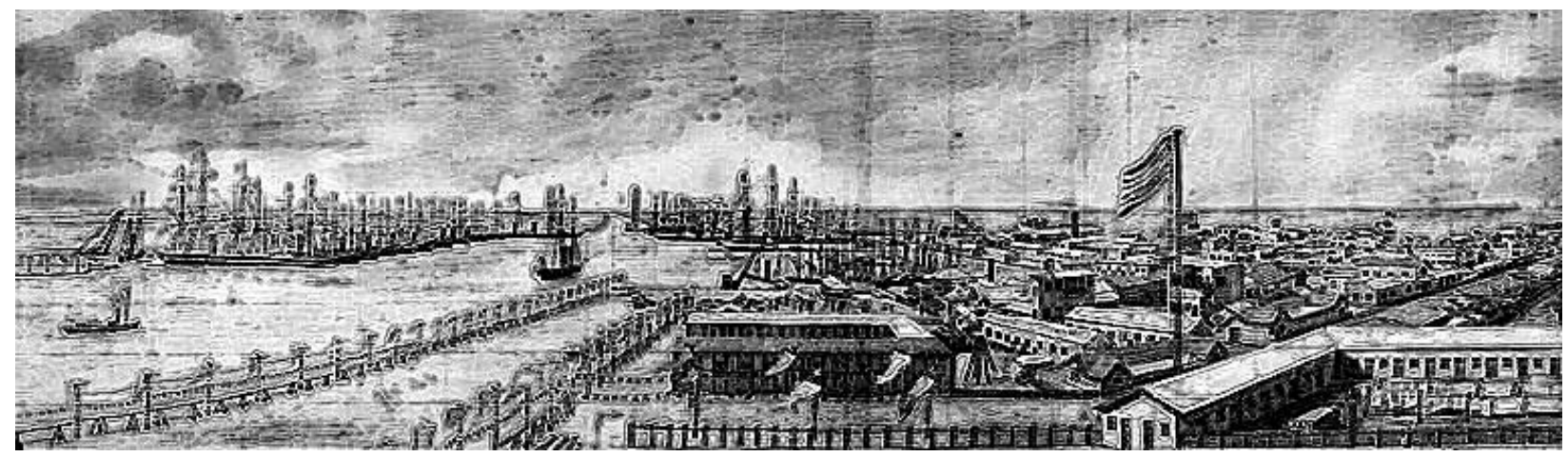

Fig. 1: Inauguration of Suez Canal in 17 November 1869 (edited by author)

Khedive Ismail was the first ruler in nine centuries to set the basis for a complete project involving a planning of a new separate quarter that would accommodate the expansion of Cairo. (Raymond, 2001) He led the process of creating the first Master plan of Cairo to mark the opening of the Suez Canal in 1869 with a huge, international celebration, to which the Kings and Presidents of Europe were invited.

Such event as inauguration of Suez Canal helped that Egypt would be recognized in the western world. Abu-Lughod commented on this issue by asking: how could Khedive Ismail invite such royalties to a city that reflected so poorly on its ruler? (Abu Lughod, 1971)
The answer to this question lies in Khedive Ismail vision for Cairo to be "The eastern Paris." His vision focused on polishing, cleaning Cairo and giving Cairo an Image of respectability. For him the solution was realistic enough to realize that it is much time saving to make a newly planned extension of the city than to dig deep into the eastern city with all its problems. The European style facade tacked onto the western edge of the old city would have to suffice. Visitors could be kept to planned itineraries that would show them only the new vigorous Cairo, comparable to their own capitals. (Abu Lughod, 1971) 


\section{IMPACT ON URBAN FABRIC:}

The rebuilding of Cairo was intended to be according to the principle of constructing an exhibition and exhibition like Cities in Europe to promote the global economic and political transformation and to symbolize its accomplishment. The new facade of the city, like the display of commodities at the exhibition, could be taken as a series of signs or representations of the larger economic changes "underneath." (Mitchell, 1991)
Khedive Ismail adopted Western development techniques and used Western experts to help make his vision real. He totally believed that copying the exact details of the European City, as a model of Urban Planning, was the only way possible to achieve any kind of development in a city like Cairo. (Raymond, 2001)

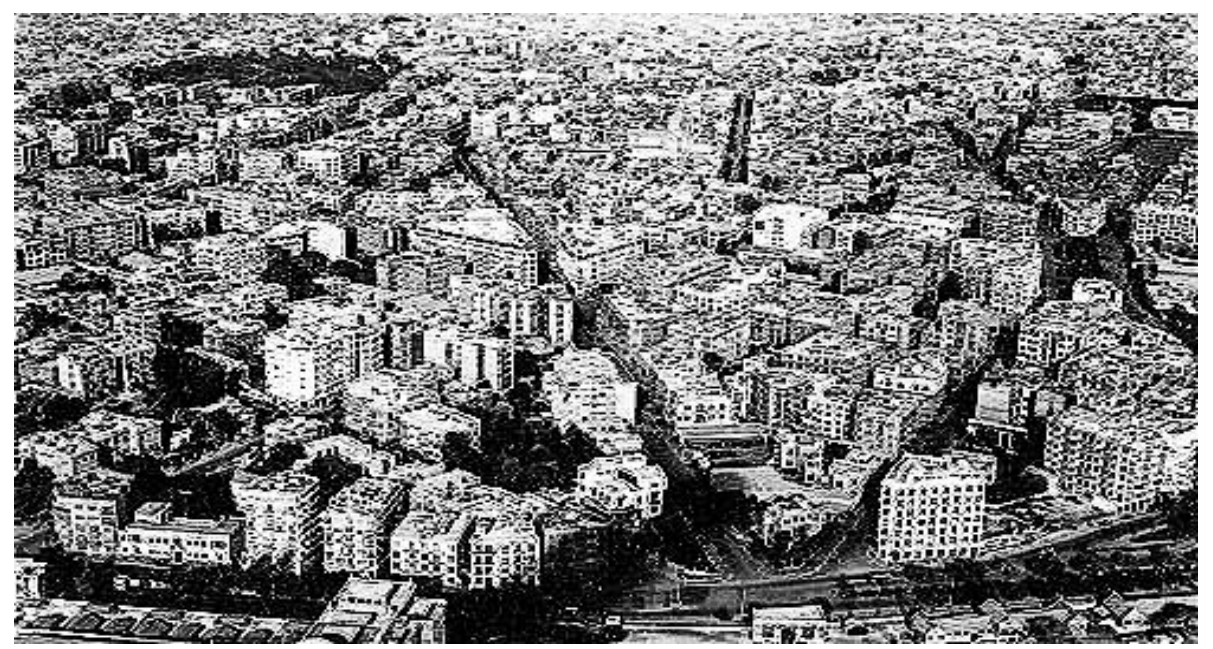

Fig. 2: Arial View showing the Khedive Ismail new development of Cairo (edited by author)

Also, an influential event during the Khedive's rule was his visit to the Exposition Universelle in Paris in 1867. (Mynetti, 1999) The exposition in Paris provided a model for the new city and stimulated much needed motivation, since it was designed to display the accomplishments of Paris to the world. This exposition affected the planning of many cities in the nineteenth century as it set the style and served as a model for many countries. It showed the new relation of Cairo to Europe which was deeply affected by the ideal incorporated in the Exposition Universelle. (Mitchell, 1991) Baron Haussmann personally welcomed Khedive Ismail and gave him extended guided tours through the "new Paris." $\mathrm{He}$ was deeply impressed by the City's reconstruction and the visit gave him renewed inspiration. (Mitchell, 1991)

Khedive Ismail, who after his meeting with Baron Haussmann in Paris in the year of 1867 had developed an enthusiasm for wide boulevards and grid planning, appointed the French educated Ali Mubarak as Minister of Public Works to oversee the commencement of a Master Plan of Cairo similar to Paris, which included the planning of new districts like Ismailiyya. Myntti explains the reason behind this was that "Khedive Ismail hungered to be civilized in the European Fashion. He knew that he must do in Cairo what Haussmann did in Paris." (Mynetti, 1999)

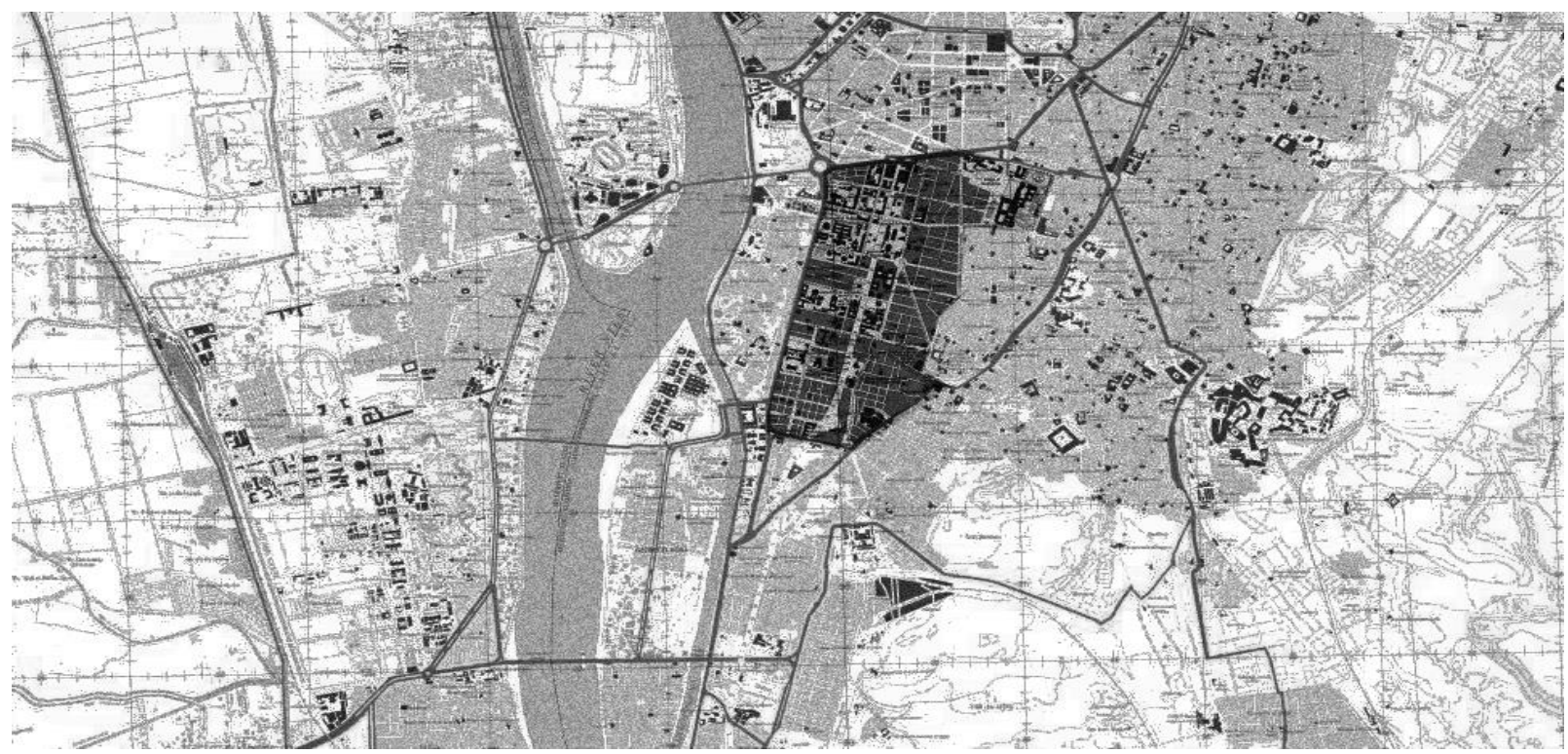

Fig. 3: Map of Cairo in 1958, the highlighted part showing the Khedive Ismail new development of Cairo (edited by author) 


\section{Cairo's Urban expansion and new Development:}

The early 19th century represents a critical period in the formation of the modern state in Egypt. During that time, Mohamed Ali who ruled Egypt from 1805 till 1848 started what could be described as the process of modernizing Egypt. Ali who headed a monarchy state was impressed by western modernity during that time. He sent many educational missions to Europe, especially to France. His period has featured one of the most dramatic shifts in the history of the city. It was a turning point from the traditional medieval era to modernization and industrialization.

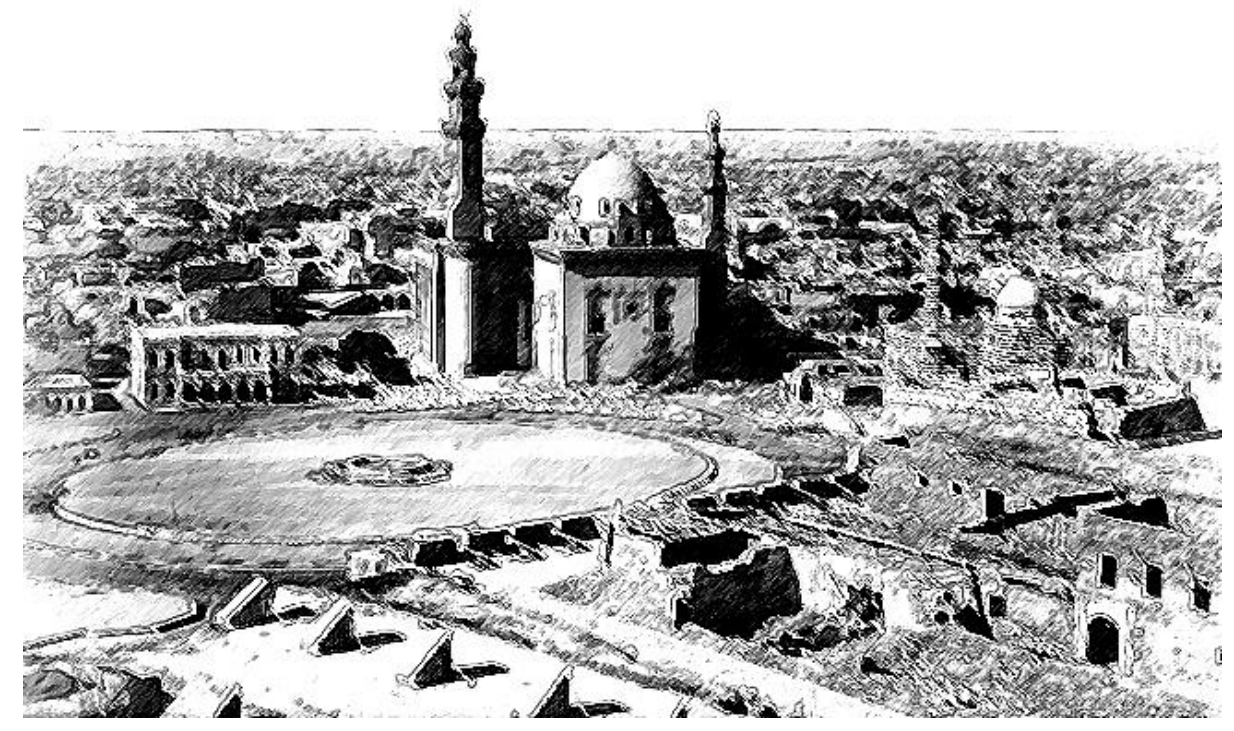

Fig. 4: Sultan Hassan Mosque in The 19th Century (edited by author)

Khedive Ismail was the first ruler in nine centuries to set the basis for a complete project to create the first Masterplan of Cairo. The newly introduced geometrical pure forms of modern planning in adjacent to the indigenous city is very contradicting. The mosque in the image is Al Sultan Hassan built in the 16th century where the square is part of the late 19th century modernization plan for Cairo.

The modernization of the physical form of Cairo began by introducing many of the Haussmann planning ideals for Paris. Straight boulevards and open squares were introduced to the city's indigenous urban fabric. The objectives were similar to those of Napoleon III. The new network of boulevards were introduced to the city not only to bring light, ventilation and facilitate flow, but also to empower the state and its control on the city. The Egyptian state that was partially controlled by colonial British establishment focused on emphasizing its power by enforcing architectural visual order. The wide boulevards facilitated the movement of armies and police. It also displayed governmental buildings at major intersections and visual focal points.

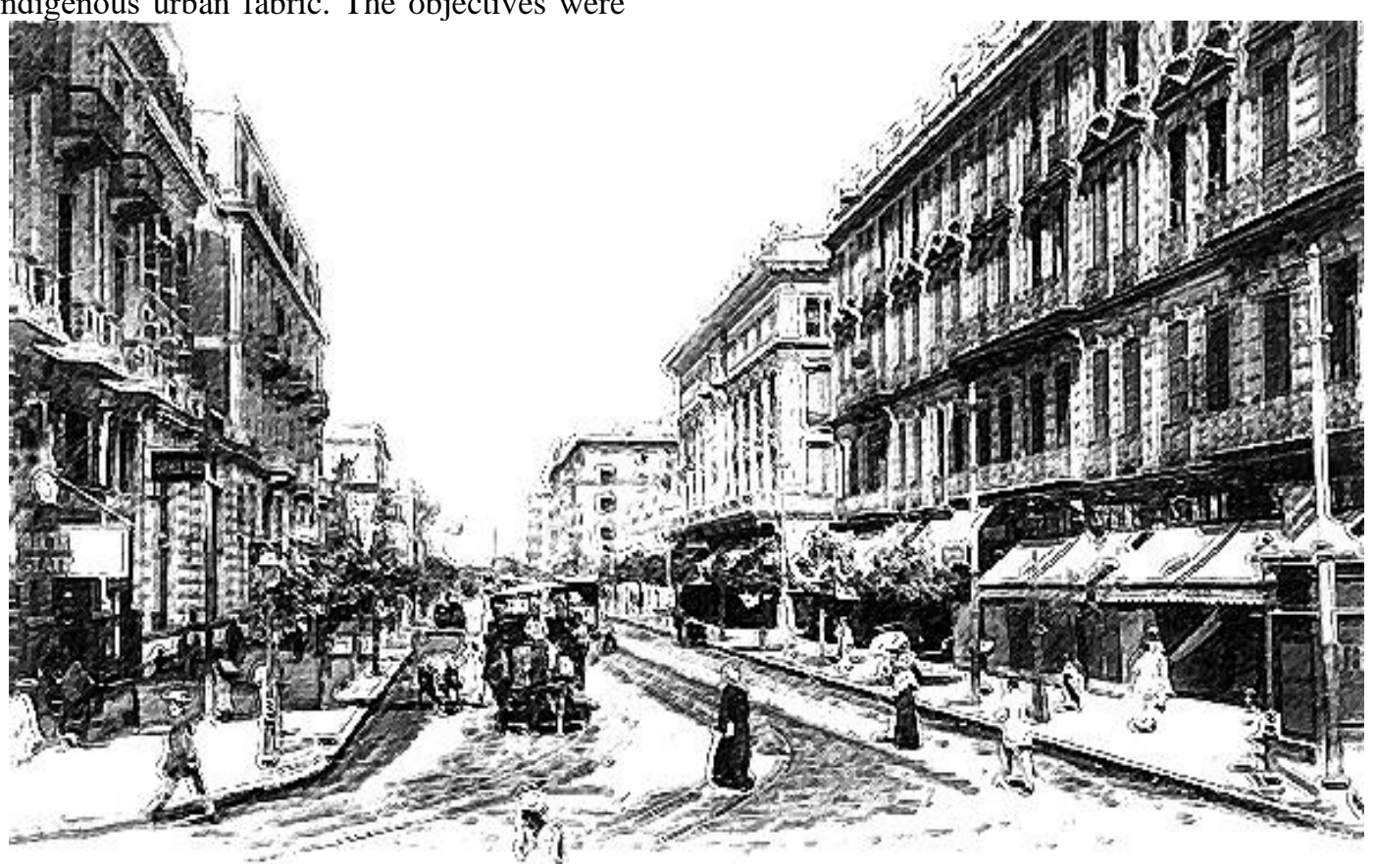

Fig. 5: Cairo 19th Century Downtown (edited by author) 
The introduction of wide boulevards fashioned after the Haussmannian model for Paris, featuring order in heights, façade treatments and connecting major squares where governmental buildings are located.

By going through the beginning of modernization that took place in downtown Cairo and its further expansion, there are several parts in this area that differs in style and is related to era and its ruler at that time. Accordingly, the urban fabric of the city center could be classified into four distinct types each reflecting a particular era and set of ideologies. There is the old medieval city, the colonial district, the modern neighborhoods and the new suburban expansions. These four parts make Cairo one of the most diverse cities in the region culturally and architecturally. It is difficult to trace a prevailing architectural style that identifies the city. Cairo is mix of old and new, western and eastern, local and global cultures, styles and social patterns.

Several expansions to the city took place afterwards in areas close to the center like Garden City and other new urban development areas like Maadi and Heliopolis. The modernization of Cairo continued accompanied by a gradual process of secularization of government. The state contribution to urban development began to gradually diminish in favor of both market and foreign flows of capital, people and ideas. Foreign investments started to flow into the city encouraged by the new privatization policies. The western influences were obvious in the Cairenes' way of life during that time. The city was opened to the western culture more than ever. The modernization of the city was a movement of the elite who benefited economically and politically from these changes. As noted by Tignor (Tignor, 1984), in the period before World War I, three groups dominated development in Egypt. These were the British political and military establishment; metropolitan capital; and landed oligarchy (Tignor, 1984). The source of metropolitan capital was different European individuals and enterprises. New urban developments as Al-Maadi, Garden City and Heliopolis began to emerge by the beginning of the 20th century. These residential districts were developed by private domestic and foreign enterprises. Garden City district was developed by Frantz Sofio, Charles Bacos and George Maksud, the owners of the Nile Land \& Agricultural Company. Heliopolis district was developed by Belgian industrialist Baron Empain, beginning in 1905. These residential developments were built for the local elite and Europeans who were living in the city. These developments made a significant change in the urban Fabric of the city. It has created new forms of class spatial segregation that didn't exist in Old Cairo.

\section{CONCLUSION}

The early 19th century represents a critical period in the formation of the modern state in Egypt.

The footprint of Cairo almost remained the same in 1848 as it had been in 1798 and the real changes were in the era of Mohamed Ali's successors. His period has featured one of the most dramatic shifts in the history of the city. It was a turning point from the traditional medieval era to modernization and industrialization. Khedive Ismail was the first ruler in nine centuries to set the basis for a complete project involving a planning of a new separate quarter that would accommodate the expansion of Cairo. He led the process of creating the first Master plan of Cairo

During the period between World War I and World War II, local industrial and commercial bourgeoisie started to play an important role in the Egyptian economy. This bourgeoisie class was composed of both foreigners and Egyptian business elite (Tignor, 1984). Low income classes didn't benefit from modernization compared to the elite. They were deprived from land ownership, university education and high governmental positions. The role of locale in the process of place production diminished allowing European influences to overwrite the identity of the city.

During the first half of the 20th century, the state contribution to urban development was minimal. It was limited to providing infrastructure and basic services. The role of market expanded on the expense of the state. Market was controlled by both European and Egyptian elites. It was for the interest of the British colonial power to keep the state weak and controlled by foreign political and military establishments. It could be argued that market and external forces flowing from the global domain were the major agencies that contributed to the production of place during this era. The exclusion of locale from this process and many other political and economic aspects has led to the gradual emergence of what Manuel Castells (Castells, 1996) calls resistance identity.

Since its origin, Cairo has been the political capital of Egypt. It hosts all the major state buildings, the majority of international organizations, embassies, transnational firms, recreational facilities, and top Egyptian universities. Cairo is by far the most important city not only in Egypt but also in the Middle East. The city has been the cultural capital of the region and the gate to popularity for Arab artists, actors and musicians. It is also the major tourist, educational and health care hub in the region.

\section{REFERENCES}

[1] Al-Sayyid Marsot, A.; A Short History of Modern Egypt; Cambridge University Press; Cambridge; $1985 ;$ p:54

[2] Abu Lughod, Janet; 1001 Years of the City Victorious; Princeton University Press; New Jersey, USA; 1971

[3] Castells, Manuel; Rise of the Network Society: The Information Age: Economy, Society and Culture, Blackwell Publishers; Cambridge, MA; September 1996

[4] Goldschmidt, Arthur; Modern Egypt: The formation of a Nation State; The American University in Cairo; Cairo; 1990

[5] Mynetti, Cynthia; Paris Along the Nile: Architecture in Cairo from Belle Epoque; Cairo; The American University in Cairo Press; 1999.

[6] Mitchell, Timothy; Colonizing Egypt; Berkeley, Los Angeles, London: University of California Press; 1991

[7] Raymond André; Cairo: City of History; American University in Cairo Press; Cairo; 2001

[8] Tignor, Robert L.; State, Private Enterprise, and Economic Change in Egypt, 1918-1952; Princeton: Princeton University Press;1984 